\title{
THE OCCURRENCE OF Cladosporium SPORES IN THE AIR AND THEIR RELATIONSHIPS WITH METEOROLOGICAL PARAMETERS
}

\author{
Agnieszka Grinn-Gofroń
}

\author{
Department of Plant Taxonomy and Phytogeography, University of Szczecin, Wąska 13, 71-415 Szczecin, Poland \\ e-mail: agofr@univ.szczecin.pl
}

Received: 27.08.2009

\section{Abstract}

Together with Alternaria, Cladosporium spores are known to be potent aeroallergens and its concentrations in the air are strongly dependent on meteorological factors. There are many articles from different parts of the world about relationships between Cladosporium spore count and weather parameters. The aim of the study was to review all available publications about Cladosporium spores in the air and compare the results in a short, useful form.

Key words: Cladosporium, airborne spores, meteorological factors, statistical correlation

\section{INTRODUCTION}

Cladosporium is one the most abundant worldwide airborne fungi. The abundance of conidia in the atmosphere is due in a large part to their ability to exist and thrive on a wide array of subsubstrates. A number of studies have confirmed that Cladosporium spores are an important aeroallergen and exposure to high concentrations affects human health by increasing the incidence of asthma and bronchial ailments (B a r n e s et al. 2001; T a riq et al. 1996). Cladosporium has relatively small spores and so airborne concentrations must reach high levels in order to induce allergenic symptoms (Brown and J a c k s o n, 1978). Gra ve se n (1979) has estimated an allergenic airborne concentration threshold of 3000 spores $\mathrm{m}^{-3}$ for Cladosporium. More recently, a figure of 4000 spores $\mathrm{m}^{-3}$ has been cited (A n o n , 2002). In Poland R a pi e j k o et al. (2004) reported that subjects with hypersensitivity to Cladosporium allergens experienced the symptoms during exposure to a concentration of approximately 2800 spores $\mathrm{m}^{-3}$ of air.

The genus Cladosporium includes over 30 species. Cladosoprium herbarium, Cladosporium cladosporoides and Cladosporium macrocarpum are all common species. The spores usually have distinctive "scars" at both ends where they were joined both to the spore at one end and to the conidiophores at the other. Although often single-celled spores, spores with a single transverse septum or several transverse septa are frequently seen. Their size ranges from 4 to 20 micrometers in length. Temperature optimum ranges from $18-28^{\circ} \mathrm{C}$, but growth down to $-6^{\circ} \mathrm{C}$ is possible (G rave s e n, 1979). Cladosporium species live on many kinds of plants. Cladosporium is soil borne and airborne, a saprophytic on dead wood, leaf debris and grasses. It is ubiquitous in the environment and a natural part of fungal flora almost everywhere. Its spores are responsible for infecting and causing plant diseases such as scab of cucumber (R ob a k and W i e ch, 1998).

\section{The highest concentrations}

Cladosporium spores are reported to form the majority of airborne spores in the temperate zones as a secondary invader of dead plants and trees (Davies, 1969). Cladosporium species live as saprophytes or as parasites on many kinds of plants. Dry spores produced in excessive quantities can be transported over wide areas, even oceans. There is a great seasonal variation in the concentration of Cladosporium conidia in the air; the highest concentrations occur during the summer from June to September (B a 11 e ro et al. 1992 - Cagliari, Perugia, Italy; E b n e r et al. 1989; H a l w a g y, 1989 - Kuwait; Ş a k i y a n and İn c e o ğ lu , 2003 - Ankara, Turkey). The highest concentration of Cladosporium during summer was observed by Hjelmroos (1993) in Sweden and by $\mathrm{S}$ tę p a l s k a et al. (1999) in Poland. The opposite occurrence was noted in Spain (Infante and Do$\mathrm{m}$ in que z, 1988) and on Sardinia (C o s e $\mathrm{n} t$ in o et al. 1990; Palmas and Cosentino, 1990) where 
a decrease in spore concentration was observed during summer. This situation has been related to the lack of rain and very high air temperature ( $\mathrm{C}$ o s e n tin o et al. 1990). In Jordan spores of Cladosporium are the most common in the air due to the wet and warm season, and maximum spore counts are noted in October (Shaneen, 1992). Oliveira et al. (2005) reported Cladosporium spores present in the air of Porto throughout the year in quite high concentrations. The first investigations of airborne fungal spores in Poland were carried out in the cities of Kraków and Rabka in 1960 (G a w e 1 et al. 1996; W e is s , 1962). Fifteen types of fungal spores were identified then, including Cladosporium which had the highest concentration in the total spore count. Many surveys of the occurrence of Cladosporium spores in different regions of the world clearly show their dominance in comparison with other spores (C a lderon et al. 1997; M itakakis et al. 1997; S haheen, 1992). Cladosporium spores had the highest concentration in the seasonal spore count. The dominance of this genus in comparison with other spores has been observed in many locations, including Denmark (Larse n and Gravese n, 1991), Spain (Fernández-Gonzáles et al. 1993; Infante and Dominquez, 1988; Infante et al. 1992), Italy (Cosentino et al. 1990; Fillipello Marchisio et al. 1997), Austria (Ebner et al. 1992), Jordan (S h a n e e n, 1992) Sweden (H je l m r o o s, 1993), India (C h a k r a b a t or y et al. 2003; S ing h et al. 1994), Canada ( $\mathrm{Li}$ and $\mathrm{Hsu}, 1995$ ), Finland (Kurkela, 1997), Australia (Mitakakis et al. 1997; M it akakis and Gues t, 2001) and in some stations in the United States (S neller and R oby, 1979).

\section{Correlations with meteorological variables Maximum temperature}

In Szczecin daily Cladosporium spore concentration has a positive, significant correlation with maximum temperature. The same correlation was noted in southern Poland (S t ę p a l s k a and W o łe k, 2005), Finland (K u r k e la , 1997), Sweden ( $\mathrm{H} \mathrm{j} \mathrm{e} \mathrm{lm}$ r o o s, 1993), Spain (Fernandez et al. 1998) and New Zealand (H a s n a in, 1993). H a s n a in (1993) also reported the strongest correlation between Cladosporium spore count and maximum day temperature in comparison with the concentrations of other airborne fungal spores.

\section{Minimum temperature}

A positive, significant correlation between spore count and minimum temperature for Cladosporium was noted in Cracow by Stę pals k a and W ołek (2005) and in Szczecin by G r i n n - G o froń (2008).
Herrero et al. (1996) found a positive correlation between minimum temperature and Cladosporium concentrations. Also F e r n a n d e z et al. (1998) observed an increase in Cladosporium spore level at a minimum temperature above $13^{\circ} \mathrm{C}$ in summer.

\section{Mean temperature}

A slight correlation between Cladosporium spore count and mean temperature, but not significant, was noted by Stępals ka and W ołek (2005) in Southern Poland (Kraków) and Mitakakis et al. (1997), S e n and A s a n (2001) reported a significant, positive correlation with average temperature in Australia and Turkey. A similar correlation, based on Spearman rank correlation test, was noted by Oliveira et al. (2009) in two rural areas of Portugal.

\section{Relative humidity}

Kurkela (1997), Sen and A s an (2001), Stępalska and Wołek (2005), Oliveira et. al. (2009) found a negative correlation between Cladosporium spore and relative humidity. During a rainy period, the level of spore concentration was low. F e r n a n d e z et al. (1998) reported that relative humidity, in connection with minimum temperature, was a factor affecting spore release. H a s n a i n (1993) did not observe an influence of relative humidity on Cladosporium spore concentration, contrary to other ascospores. K a t i a 1 et al. (1997) noted a positive correlation between Cladosporium spore count and relative humidity.

\section{Rainfall}

A slight correlation between precipitation and the number of Cladosporium spores was observed in Finland by K u r k e l a (1997). Only in one season did rain have a significant correlation with the number of spores counted 14 hours later. $\mathrm{H} \mathrm{j} \mathrm{e} \mathrm{lm}$ r o os (1993) noted that the increase in atmospheric concentrations after rainfall is generally long lasting, with the peak observed some hours after the rain. $\mathrm{K}$ atial et al. (1997), Mitakakis et al. (1997), S e n and A s a n (2001), O live ir a et al. (2009) reported a negative correlation with rain for Cladosporium.

\section{Wind speed}

During the seasons in question, the correlation between Cladosporium spore concentration and wind speed did not show a statistically significant correlation. The same results were noted by Levetin and Dorsey (2006), Has nain (1993), L opez and S a lv a g g i o (1983). Wind speed was clearly associated with spore dispersal in Finland ( $\mathrm{Kurkela}$, 
1997), in Turkey (S e n and A s a n, 2001) and in Portugal (O live i r a et. al. 2007). The long-distance dispersal of spores depends on wind conditions, but the detachment of spores dispersed in dry conditions is also strongly influenced by wind ( $\mathrm{Malla} \mathrm{ia} \mathrm{h}$ and $\mathrm{R}$ a o, 1982).

\section{Pressure}

In contrast to the positive relationship with temperature, the concentration of Cladosporium spores was significantly and negatively correlated with air pressure. That correlation was noted only in one analysed season (Grinn-Gofroń, 2008). H jelm ro os (1993) noted the same results for Cladosporium in Sweden. A positive, significant correlation during one season in spring was reported by $\mathrm{Tr}$ o u t $\mathrm{t}$ and Le vet in (2001) from the United States.

\section{Dew point temperature}

Has nain (1993) reported that dew point might play a secondary role in Cladosporium release but, as the atmosphere warmed, more Cladosporium seemed to be found in the air. A significant, negative correlation between Cladosporium spore count and dew point was noted in multiple regression analysis employed by Troutt and Levetin (2001). They noted that the temperature and dew point seemed to be the most important meteorological factors associated with Cladosporium.

\section{Statistical models}

Meteorological conditions clearly have a profound influence on the production, dispersal and deposition of fungal spores. The influence of meteorological factors on the concentrations of airborne fungal spores appears to be additive, not independent. The relationship might also be multiplicative and non-linear. Hence, the best statistical method which gives the most reliable results is the predictive model.

There are some forecasting models for Cladosporium spore concentration and meteorological parameters.

Li and Kendrick (1995) created a statistical model using CANOCO analysis which contains the data for eight types of spores in one-year study. The concentrations of Cladosporium spore were significantly correlated only with mean temperature. This factor was considered as the most important by the authors.

K a t i a 1 et al. (1997) found a direct correlation with relative humidity and average temperature and inverse correlation with precipitation. They used time series analysis for three spore types in a eight-year study cycle. Their model incorporated the annual cycle and serial correlations of the errors with regard to spore variability. However, this method did not show the exact value of the key parameters correlated.

A more simple analysis to create a statistical model was used by Troutt and Levetin (2001) in Tulsa (United States). Multiple regression showed a positive, significant correlation between Cladosporium spore concentrations and temperature. This correlation was calculated for the two spring months during the two years of research.

Hollins et al. (2004) created multiple linear regression models using the number of days above threshold as the response variable against the climatic variables. The number of days in summer when Cladosporium spores were above the allergenic concentration was positively correlated with regional temperature and negatively correlated with precipitation over the study period.

The autoregressive predictive models created by Damialis and Gioulekas (2006) proved to be of high forecasting ability for the circulation of fungal spores in Thessaloniki, Greece, explaining the greatest variance of the time series and with relatively low forecast error. The obtained results showed that Cladosporium spores were strongly related to solar radiation.

The sporulation and dispersion of Cladosporium spores are closely related to variations in atmospheric conditions. Therefore, there is an increasing interest in the development of statistical models of high predictive power for atmospheric levels of airborne fungal spores that will allow allergic individuals to take preventative action.

For the abovementioned reasons, it was the first time that Cladosporium spore level was forecasted in Poland by Grinn-Gofroń and Strzelczak (2008).

Spearman's rank correlations for the whole data set showed a direct correlation with dew point temperature, three temperature parameters (maximum, minimum and average) and inverse correlation with relative humidity, average and maximum wind speed. Similar results were observed for spore seasons, although correlation level decreased with lags and was lower. The presence of many 0 values in Cladosporium variable probably overstated Spearman's correlation coefficients for the whole data set. ANN models confirmed the importance of the above listed parameters. The classification model indicated dew point temperatures ( 3 days prior, the same day and 2 days prior) as the most important variables, while the regression model for spore seasons - dew point temperature recorded the previous day, then humidity, maximum temperature on the same day and with lag 1.

It is confirmed that the ANN method gives the possibility to forecast satisfactorily Cladosporium 
spore concentration. It has turned out that time series with many 0 values are quite difficult to predict, since they actually contain 2 subsets (equal to 0 and higher than 0). Two ways of forecasting Cladosporium spore concentration are proposed in this study. The first model includes classification of spore presence or absence with good accuracy, and the focus on the prediction of $\log (\mathrm{x}+1)$ transformed spore concentration during spore seasons. The second modelling possibility is to use time series prediction, based on meteorological parameters and other unknown factors, "hidden" in spore concentration values recorded in one sample year. Both of those forecasting methods revealed satisfactory performance and we believe that they can be successfully applied in other regions.

\section{CONCLUSIONS}

- Maximum, mean and minimum temperature was positively and statistically significantly correlated with Cladosporium spore concentration.

- A negative correlation was found for three weather parameters: rainfall, pressure and dew point temperature. The last factor was identified as the most important.

- No authors found significant, statistical relationships with wind speed.

- There was an unclear situation in the case of relative humidity. Some authors noted a positive correlation and others a negative one. In several cases, a statistically significant correlation did not occur.

- In the statistical models, the most important factors influencing the concentration of Cladosporium spores were mean temperature and dew point temperature. A positive correlation occurred between spores and relative humidity and negative with rainfall.

- Because despite of many various studies, the weather factors affecting the concentration of spores in the air are not defined precisely and unambiguously, the research methodology should be continually improved.

\section{REFERENCES}

A n on 2002. Fin Pollen Bull. (Suppl). 26; 2.

Ballero M., Gioannis N., de Goretti G., Lombardini S., Frenquelli G., 1992. Comparative study about airborne spores in Caligari and Perugia. Aerobiologia, 8: 141-147.

Barnes C., Tuck J., Simon S., Pacheco F., Hu F., Portnoy J., 2001. Allergenic materials in the house dust of clinical patients. Ann. Allergy Asthma Immunol. 86: 517-523.

Brown H. M., Jacks on F. A., 1978. The value of aerobiology to an allergy treatment centre. In: Federal en- vironmental Agency (eds) Proceedings of the First International Conference on Aerobiology, Munich, 13-15 August. Erich Schmidt, Berlin: 278-286.

Calderon C., Lacey J., McCartney A., Rosas I., 1997. Influence of urban climate upon distribution of airborne Deuteromycetes spore concentrations in Mexico City. Int. J. Biometeorol. 40: 71-80.

Chakraborty P., Gupta-Bhattacharya S., Sunir$\mathrm{m}$ a $1 \mathrm{Ch} ., 2003$. Aeromycoflora of an agricultural farm in West Bengal, India. A five-year study (1994-1999). Grana, 42: 248-254.

Cosentino S., Pisano P. L, Fadda M. F., Palmas F., 1990. Pollen and mould allergy: aerobiological survey in the atmosphere of Caligari, Italy (1986-1988). Ann. Allergy, 65: 393-399.

Damialis A., Gioulekas D., 2006. Airborne allergenic fungal spores and meteorological factors in Greece: Forecasting possibilities. Grana, 45: 122-129.

Davies R. R., 1969. Spore concentrations in the atmosphere at Ahmadi, a new town in Kuwait. J. Gen. Microbiol. 55: 425-432.

Ebner M. R., Haselwandter K., Frank, A., 1989. Seasonal fluctuations of airborne fungal allergens. Mycol. Res. 92: 170-176.

Ebner M. R., Haselwandter K., Frank A., 1992. Indoor and outdoor incidence of airborne fungal allergens at low- and high-altitude alpine environments. Mycol. Res. 96: 117-124.

Fernández D., Valencia R. M., Molnar T., Vega A., S a gues E., 1998. Daily and seasonal variations of Alternaria and Cladosporium airborne spores in Leon (North-West, Spain). Aerobiologia, 14: 215-220.

Fernández-Gonzáles D., Suárez-Cervera M., Diaz-Gonzáles T., Valencia-Barrera R. M., 1993. Airborne pollen and spores of León (Spain). Int. J. Biometeorol. 37: 89-95.

Filipello Marchisio V., Airaudi D., Barchi C., 1997. One-year monitoring of the airborne fungal community in a suburb of Turin (Italy) and assessment of its functional relations with the environment. Mycol. Res. 101: 821-828.

Gaweł J., Halota A., Pisiewicz K., Kurzawa R., Radliński J., Doniec Z., 1996. Allergenic airborne sporomorphs calendar for Rabka (southern Poland), 1991-1995. Ann. Agric. Environ. Med. 3: 87-98.

Gravesen S., 1979. Fungi as a Cause of Allergic Disease. Allergy, 34: 135-154.

Grinn-Gofroń A., 2008. The variation in spore concentrations of selected fungal taxa associated with weather conditions in Szczecin, Poland, 2004-2006. Grana, 47: 139-146.

Grinn-Gofroń A., Strzelczak A., 2008. Artificial neural network models of relationships between Cladosporium spores and meteorological factors in Szczecin (Poland). Grana, 47: 304-314.

Halwagy M., 1989. Seasonal airspora at the three sites in Kuwait 1977-1982. Mycol Res. 93: 208-213. 
Hasnain S. M., 1993. Influence of meteorological factors on the air spora. Grana, 32: 184-188.

Herrero B., Fombella-Blanco M. A., FernándezGonzález D., Valencia-Barrera R. M., 1996. The role of meteorological factors in determining the annual variation of Alternaria and Cladosporium spores in the atmosphere of Palencia, 1990-1992. Int. J. Biometeorol. 39: 139-142.

Hjel m roos M., 1993. Relationship between airborne fungal spore presence and weather variables. Grana, 32: 40-47.

Hollins P. D., Kettlewell P. S., Atkinson M. D., Stephenson D. B., Corden J. M., Millington W. M., Mullins J., 2004. Relationships between airborne fungal spore concentration of Cladosporium and the summer climate at two sites in Britain. Int. J. Biometeorol. 48: 137-141.

Infante F., Dominquez E., 1988. Annual variation of Cladosporium spores in home habitats in Cordoba, Spain. Ann. Allergy, 60: 256-261.

Infante F., Galan-Soldevilla C., DominquezVilches E., Angulo-Romero J., Mediavilla-Molina A., 1992. Air spore microfungi in dwellings of south of Spain. Aerobiologia, 8: 245-253.

Katial R. K., Zhang Y. M., Jones R. H., Dyer P. D., 1997. Atmospheric mold spore counts in relation to meteorological parameters. Int. J. Biometeorol. 41: 17-22.

Kurkela T., 1997. The number of Cladosporium conidia in the air in different weather conditions. Grana, 36: 5461.

Larsen L., Grave sen S., 1991. Seasonal variation of outdoor airborne viable microfungi in Copenhagen, Denmark. Grana, 30: 467-471.

Levet in E., Dorsey K., 2006. Contribution of leaf surface fungi to the air spora. Aerobiologia, 22: 3-12.

Li C., H s u L., 1995. Fungus allergens inside and outside the residences of atopic and control children. Arch. Environ. Health, 50: 38-43.

Li D-W., Kendrick B., 1995. A year-round study on functional relationships of airborne fungi with meteorological factors. Int. J. Biometeorol. 39: 74-80.

Lopez M., S alvaggio E. J., 1983. Climate-Weather-Air pollution. [In:] E. Middleton, C. E. Reed \& E. F. Ellis (eds), Allergy: Principle and practice, C. V. Mosby St. Louis-Toronto.

Mallaiah K., Rao A. S., 1982. Aerial dissemination of uredinospores of groundnut rust. Trans. Br. Mycol. Soc. 78: 21-28.

Mitakakis T. Z., Guest D. I., 2001. A fungal spore calendar for the atmosphere of Melbourne, Australia, for the year 1993. Aerobiologia, 17: 171-176.

Mitakakis T., Ong E. K., Stevens A., Guest D., Knox R. B., 1997. Incidence of Cladosporium, Alternaria and total fungal spores in the atmosphere of Melbourne (Australia) over 3 years. Aerobiologia, 13: 83-90.
Oliveira M., Abreu I., 2005. Effects of some meteorological factors on fungal spore distribution in Porto Atmosphere. Annalen der Meteorologie, 41: 162-165.

Oliveira M., Abreu I., Ribeiro H., Delgado L., 2007. Fungal spores in the atmosphere in the city of Porto and its allergological implications. Rev. Port. Imunoalergologia. 15 (1): 61-85.

Oliveira M., Ribeiro H., Delgado L., Abreu I., 2009. The effects of meteorological factors on airborne fungal spore concentration in two areas differing in urbanization level. Int. J. Biometeorol. 53: 61-73.

Palmas F., Cosentino S., 1990. Comparison between fungal airspora concentration at two different cities in the South of Sardinia. Grana, 29: 87-95.

Rapiejko P., Lipiec A., Wojdas A., Jurkiewicz D., 2004. Threshold pollen concentration necessary to evoke allergic symptoms. Int. Rev. Allergol. Clin. Immunol. 10 (3): 91-94.

R ob ak, J., Wi e ch, K., 1998. Choroby i szkodniki warzyw. Plantpress, Kraków.

Şakiyan N., Inceo ğlu Ö., 2003. Atmospheric concentrations of Cladosporium Link and Alternaria nees spores in Ankara and the effects of meteorological factors. Turk. J. Bot. 27: 77-81.

Şen B., Asan A., 2001. Airborne fungi in vegetable growing areas of Edirne, Turkey. Aerobiologia, 17: 69-75.

Shaheen I., 1992. Aeromycology of Amman area, Jordan. Grana, 31: 223-228.

Singh A., Gangal S. V., Singh A. B., 1994. Airborne fungi in the hospitals of metropolitan Dehli. Aerobiologia, 10: 11-21.

Sneller M., Roby R. R., 1979. Incidence of fungal spores at the homes of allergic patients in an agricultural community. I. A 12-month study in and out of doors. Ann. All. 43: 225-228.

Stępalska D., Wołek J., 2005. Variation in fungal spore concentrations of selected taxa associated to weather conditions in Cracow, Poland, in 1997. Aerobiologia, 21: 43-52.

Stępalska D., Harmata K., Kasprzyk I., Myszkowska D., Stach A., 1999. Occurrence of airborne Cladosporium and Alternaria spores in Southern and Central Poland in 1995-1996. Aerobiologia, 15: 39-47.

Tariq S. M., Matthews S. M., Stevens M., Hakim E. A., 1996. Sensitization to Alternaria and Cladosporium by the age of 4 years. Clin. Exp. Allergy, 26: 794-798.

Troutt C., Levetin E., 2001. Correlation of spring spore concentrations and meteorological conditions in Tulsa, Oklahoma. Int. J. Biometeorol. 45: 64-74.

We is s A., 1962. Über das Pilzsporenvorkommen in der Luft in Kraków und Bad Rabka. Allerg. Asthma, 8: 298303. 


\section{Występowanie zarodników Cladosporium w powietrzu i ich korelacje z czynnikami pogody}

\section{Streszczenie}

Zarodniki rodzaju Cladosporium są najczęściej i najliczniej notowanym taksonem grzybowym w większości stacji badawczych na świecie. Są też, razem $\mathrm{z}$ rodzajem Alternaria, uznane za czynnik wywołujący objawy alergii i astmy w okresie letnim czyli podczas wysokich temperatur i przy braku opadów. Było to powodem podjęcia prób określenia który z czynników pogody ma najsilniejszy wpływ na wysokość ich koncentracji w powietrzu.

Statystycznie istotne, pozytywne korelacje były notowane dla dobowych temperatur maksymalnych, średnich i minimalnych a negatywne dla wysokości opadów deszczu i ciśnienia atmosferycznego.

Żaden $\mathrm{z}$ autorów nie zanotował istotnej statystycznie korelacji pomiędzy stężeniem zarodników rodzaju Cladosporium a prędkością wiatru.
W prognostycznych modelach statystycznych najważniejszymi czynnikami meteorologicznymi wpływającymi na obecność zarodników Cladosporium w powietrzu była średnia temperatura powietrza i temperatura punktu rosy.

Przy obecnym stanie badań nad relacjami statystycznymi pomiędzy obecnością (stężeniem) zarodników w powietrzu a czynnikami meteorologicznymi warto popracować nad ulepszeniem istniejących metod badawczych lub zastosowaniem nowych, które precyzyjniej i bardziej jednoznacznie określiłyby rangę poszczególnych czynników meteorologicznych. 